\title{
Pengaruh Kombinasi Latihan Beban dengan Metode Pyramid set dan Konsumsi Susu Tinggi Protein Terhadap Peningkatan Massa Otot
}

\author{
Melfi Triani Siska ${ }^{1 *}$, Zahtamal ${ }^{2}$, Fachriani Putri ${ }^{2}$
}

\begin{abstract}
Weight training with pyramid set method and high protein milk are the effective methods to increase muscle mass. There are not many studies that combined these 2 methods to increase the muscle mass. The purpose of this study was to analyze the effect of combination of pyramid weight training sets and consumption of high protein milk to increase the muscle mass. This type of study is a quasi-experimental one group with a pre and post test design. The study period was 8 weeks with 32 meetings and high protein milk in of 32 grams of whey protein concentrate before and after exercise.The results of this study also prove that there is a significant effect of intervention on participants muscle mass with $\mathrm{p}=0,000$. It can be concluded that the combination of pyramid weight training sets and high protein milk consumption is effective to increasing muscle mass.
\end{abstract}

Keywords: high protein milk, muscle mass, pyramid method, weight training

Bentuk tubuh yang ideal dan atletis merupakan suatu hal yang sangat diinginkan oleh setiap orang dalam kehidupan. ${ }^{1}$ Hal ini terlihat dari beberapa kompetisi tubuh dengan jumlah peserta yang makin meningkat dari tahun ke tahun. Kompetisi tersebut membuat peserta menjadi termotivasi untuk memiliki bentuk tubuh yang diinginkan setiap orang. ${ }^{2}$ Berbagai cara dan upaya dilakukan untuk mendapatkan bentuk tubuh yang ideal. Salah satunya dengan melakukan aktivitas fisik atau berolahraga. Olahraga yang sering dilakukan adalah latihan beban yang terukur, teratur dan terprogram di pusat-pusat kebugaran (fitness center). ${ }^{1}$

Latihan beban merupakan salah satu program yang dapat membentuk massa otot agar tubuh menjadi atletis. ${ }^{1}$ Latihan beban dapat menambah massa otot, keadaan ini disebut dengan hipertrofi otot . Hipertrofi otot adalah pembesaran serat otot yang disebabkan oleh peningkatan jumlah filamen aktin dan miosin dalam setiap serat otot. ${ }^{3}$ Berbagai macam metode latihan untuk menyusun atau

\footnotetext{
* Penulis untuk korespondensi : Email : melfitrianisiska@ gmail.com

1 Program Studi Kedokteran Fakultas Kedokteran Universitas Riau, Pekanbaru, Riau, Indonesia.

2 KJFD IKM/IKK Fakultas Kedokteran Universitas Riau, Pekanbaru, Riau, Indonesia.
}

merancang program latihan, diantaranya metode super set, compound set, drop set, dan pyramid set. $^{2}$

Metode pyramid set merupakan metode yang dapat menyebabkan peningkatan besar dalam hal kekuatan otot dibandingkan dengan metode yang lain. Hal ini disebabkan oleh latihan yang dilakukan dari intensitas rendah ke intensitas tinggi sehingga dapat mempertahankan resistensi latihan. Resistensi latihan juga akan mengakibatkan kekuatan dan massa otot meningkat. Metode pyramid set adalah metode latihan yang sistem repetisi awalnya banyak tetapi beban yang diberikan tetap ringan, dan set selanjutnya repetisi berkurang akan tetapi beban latihan yang diberikan makin bertambah. ${ }^{4}$

Peningkatan massa otot juga harus diiringi dengan mengonsumsi asupan protein. Karena pada saat melakukan latihan beban kebutuhan asupan protein meningkat. Hal ini disebabkan karena terjadi kerusakan jaringan otot terutama dalam melakukan latihan berat. Peningkatan asupan protein diperlukan untuk meningkatkan sintesis protein dalam membantu proses perbaikan dan remodelling serat otot rangka yang rusak akibat latihan yang berat. ${ }^{5}$ Salah satu upaya untuk meningkatkan asupan protein melalui konsumsi susu tinggi protein. Konsumsi susu tinggi 
protein merupakan salah satu upaya untuk meningkatkan asupan protein. Kandungan protein pada susu secara tidak langsung dapat memperbaiki metabolik tubuh sehingga dapat mengontrol berat badan dan komposisi tubuh. ${ }^{6}$ Asam amino esensial dan non esensial dapat bertindak sebagai substrat dalam sintesis sehingga dapat mempengaruhi komposisi tubuh dan meningkatkan indeks massa tubuh.

Susu tinggi protein mengandung dua komponen protein yaitu protein utama dan protein whey. Kadar kasein pada protein susu mencapai $80 \%$ dari jumlah protein yang terdapat dalam susu sapi, sedangkan protein whey sebanyak 20\%. Kandungan protein whey berhubungan dengan peningkatan massa otot. Susu tinggi protein merupakan salah satu sumber protein yang memiliki nilai biologis yang tinggi. Salah satu untuk mengukur kualitas protein. yaitu menghitung nilai Protein Efficiency Ratio (PER). Nilai PER yang tinggi pada protein berhubungan dengan peningkatan berat badan individu. ${ }^{6}$

Penelitian Rabi dkk (2012) tentang pengaruh latihan beban terhadap peningkatan massa otot pectoralis mayor dan biceps pada remaja dan dewasa di Maha Gym Batubulan Gianyar dan Penelitian Putra (2015) tentang pengaruh latihan beban dengan metode pyramid set terhadap massa otot dada member fitness di pesona merapi gym telah membuktikan bahwa ada pengaruh latihan beban dengan metode pyramid set untuk meningkatkan massa otot pada remaja. ${ }^{2,7}$ Penelitian Setiowati (2015) tentang pengaruh suplementasi protein terhadap komposisi tubuh pada atlit dan penelitian Harna (2017) tentang intervensi susu tinggi protein terhadap tingkat konsumsi zat gizi makro dan status gizi pada kelompok usia dewasa telah membuktikan ada manfaat susu tinggi protein dalam peningkatan konsumsi protein, massa otot dan meningkatkan indeks massa tubuh. ${ }^{5,6}$ Namun belum banyak penelitian mengenai pengaruh kombinasi latihan beban dengan pyramid set dan konsumsi susu tinggi protein secara bersamaan untuk meningkatkan massa otot. Berdasarkan uraian di atas, perlu dilakukan penelitian tentang pengaruh kombinasi latihan beban dengan pyramid set dan konsumsi susu tinggi protein terhadap peningkatan massa otot. Tujuan penelitian ini untuk mengetahui karakteristik responden berdasarkan umur dan
Indeks Massa Tubuh serta menganalisis pengaruh kombinasi latihan beban dengan pyramid set dan konsumsi susu tinggi protein terhadap peningkatan massa otot.

\section{METODE}

Jenis penelitian ini adalah kuasi eksperimen dengan one group with pre and pos test design. Penelitian ini dilakukan di salah satu pusat kebugaran di Kota Pekanbaru. Penelitian ini dilakukan pada bulan Agustus - Desember 2018. Penelitian dilakukan setelah dinyatakan lulus kaji etik kedokteran (ethical-clearance) dari Unit Etika Penelitian Fakultas Kedokteran Universitas Riau dengan nomor 196c/UN.19.5.1.1.8/UEPKK/2018/ rev-1.

Populasi pada penelitian ini adalah seluruh anggota fitness yang mengikuti program latihan di salah satu Pusat Kebugaran di Kota Pekanbaru. Jumlah sampel pada penelitian ini 15 orang yang dipilih dengan metode quota sampling yang memenuhi kriteria inklusi. Kriteria inklusi dalam penelitian ini adalah jenis kelamin laki-laki, usia $\geq 15$ tahun dan bersedia menjadi partisipan. Anggota yang telah didiagnosis menderita asma yang dipicu oleh aktivitas fisik dan memiliki alergi susu sapi dimasukkan dalam kriteria eksklusi. Anggota yang tidak melanjutkan/mengikuti program kurang dari 8 minggu, tidak mengonsumsi susu yang diberikan selama 3 hari berturut-turut, meninggal, menolak atau berhenti secara sepihak menjadi partisipan, dan mengundurkan diri atau hilang tanpa kabar berita sehingga tidak bisa diambil sebagai sampel dan dimasukkan dalam kritertia drop out.

Jenis data yang digunakan dalam penelitian adalah data kuantitatif, berupa hasil pengukuran massa otot yang bersumber secara primer dari responden baik sebelum dan setelah diberi intervensi kombinasi latihan beban dengan metode pyramid set dan konsumsi susu tinggi protein. Latihan beban metode pyramid set dilakukan selama 8 minggu dengan frekuensi 4 kali dalam seminggu, 8-12 kali ulangan/set dan intensitas 70-80\% dari kemampuan maksimal. dan konsumsi susu tinggi protein diberikan dalam bentuk whey protein concentrate sebesar 32 gr (64\% Per Serving/penyajian) dengan gelas ukur $420 \mathrm{ml}$ yang diminum sebelum dan setelah melakukan 
latihan beban.

Teknik pengumpulan data dalam penelitian ini berupa menggunakan lembar informed consent, lembar isian responden, dan pita ukur dengan satuan centimeter untuk mengukur massa otot. Adapun otot yang dilihat dan diukur adalah otot besar terdiri dari otot perut, otot dada, otot lengan atas, otot lengan bawah dan otot bahu. Untuk melihat efektivitas intervensi dilakukan uji statistik, dengan taraf signifikansi yang dipergunakan $\mathrm{p}<0,05$. Efek dari intervensi dianalisis dengan menggunakan repeated anova dan uji pair wise comparison.

\section{HASIL}

Jumlah sampel dalam penelitian ini 15 responden. Karakteristik responden berdasarkan umur dan Indeks Massa Tubuh (IMT) dapat dilihat pada tabel 1 berikut:

Tabel 1. Distribusi responden berdasarkan umur dan IMT

\begin{tabular}{lll}
\hline Variabel & Rata-rata & Standar deviasi \\
\hline Umur & 19,27 & 3,453 \\
IMT Pra intervensi & 18,26 & 1,62 \\
IMT 1 bulan intervensi & 18,73 & 1,49 \\
IMT 2 bulan intervensi & 19,15 & 1,4 \\
\hline
\end{tabular}

Pada penelitian ini umur terendah dan tertinggi responden adalah 15 tahun dan 26 tahun. Berdasarkan Tabel 1 di atas diketahui bahwa gambaran rerata umur responden adalah 19,27 tahun dengan standar deviasi 3,453. Selanjutnya, diketahui bahwa terjadi peningkatan skor Indeks Massa Tubuh (IMT) dari minggu ke minggu selama 2 bulan intervensi. Rerata IMT sebelum intervensi adalah 18,26 (SD 1,62), pada akhir bulan pertama reratanya meningkat menjadi 18,73 (SD 1,49), dan pada akhir bulan kedua menjadi 19,15 (SD 1,40).

Berdasarkan hasil ini diketahui bahwa kombinasi latihan beban dengan metode pyramid set dan konsumsi susu tinggi protein terbukti dapat meningkatkan IMT. Trend peningkatan IMT responden dapat dilihat pada gambar 1 berikut ini:

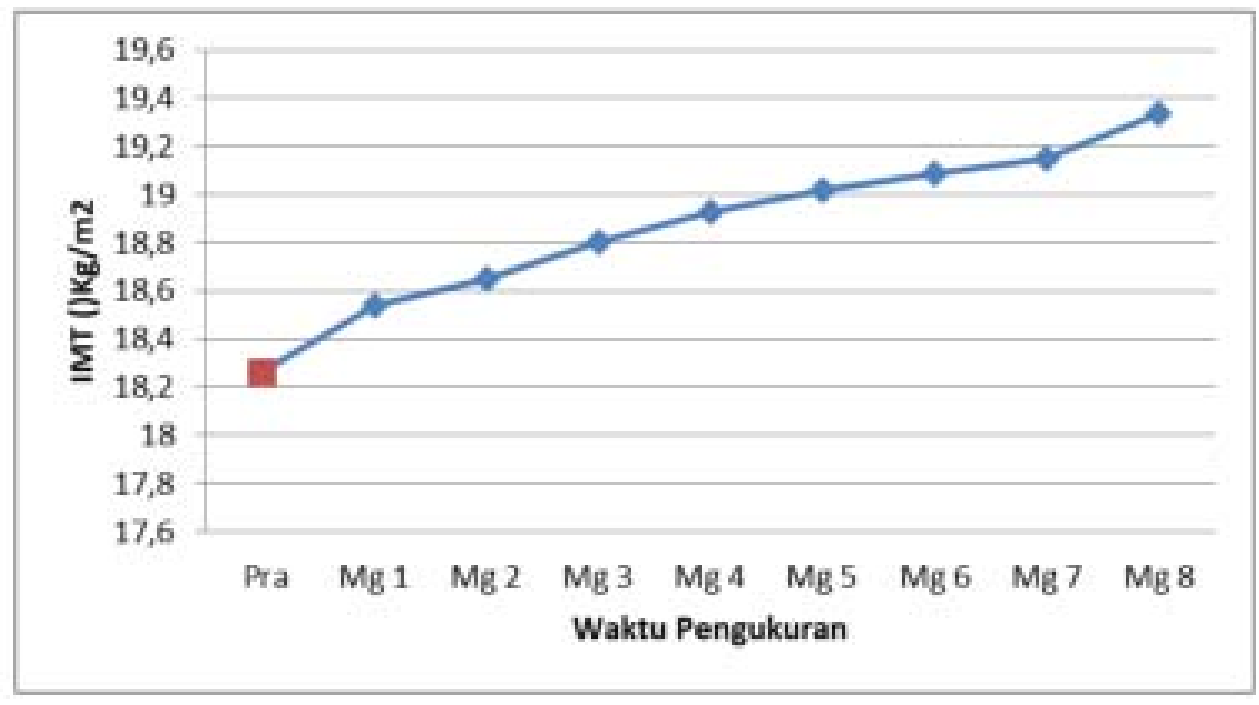

Gambar 1. Trend peningkatan IMT responden 
Berdasarkan pengolahan data variabel massa otot, diketahui bahwa terjadi peningkatan rerata massa otot responden dari sebelum intervensi, satu bulan intervensi dan di akhir bulan ke dua intervensi. Hal ini dapat dilihat pada tabel 2 berikut ini:

Tabel 2. Uji beda rerata massa otot sebelum, satu bulan intervensi dan di akhir bulan ke dua intervensi

\begin{tabular}{lcccc}
\hline Jenis Otot & Pra intervensi & 1 bulan intervensi & 2 bulan intervensi & $\begin{array}{c}\text { Uji beda antar } \\
\text { pengulangan (p) }\end{array}$ \\
\cline { 2 - 4 } & $\begin{array}{c}\text { Rerata dan } \\
\text { sebaran data }\end{array}$ & $\begin{array}{c}\text { Rerata dan } \\
\text { sebaran data }\end{array}$ & $\begin{array}{c}\text { Rerata dan sebaran } \\
\text { data }\end{array}$ & \\
\hline Otot perut & $68,80 \pm 6,7$ & $70,67 \pm 6,32$ & $72,70 \pm 6,54$ & 0,003 \\
Otot dada & $82,13 \pm 5,69$ & $85,62 \pm 5,44$ & $87,92 \pm 5,51$ & 0,000 \\
$\begin{array}{l}\text { Otot lengan } \\
\text { atas }\end{array}$ & $28,20 \pm 2,65$ & $30,28 \pm 2,75$ & $31,63 \pm 2,70$ & 0,000 \\
$\begin{array}{l}\text { Otot lengan } \\
\text { bawah }\end{array}$ & $24,80 \pm 2,37$ & $26,27 \pm 1,77$ & $27,52 \pm 1,69$ & 0,000 \\
Otot bahu & $101,20 \pm 6,34$ & $104,95 \pm 6,07$ & $106,68 \pm 5,77$ & 0,000 \\
\hline
\end{tabular}

Berdasarkan tabel 2 di atas diketahui bahwa:

a) Nilai massa otot perut pada saat sebelum intervensi adalah $68,80 \mathrm{~cm}$, satu bulan intervensi $70,62 \mathrm{~cm}$ dan dua bulan intervensi $72,70 \mathrm{~cm}$ sehingga terdapat perbedaan bermakna seiring berjalannya waktu.

b) Nilai massa otot dada pada saat sebelum intervensi adalah $82,13 \mathrm{~cm}$, satu bulan intervensi $85,62 \mathrm{~cm}$ dan dua bulan intervensi 87,92 cm sehingga terdapat perbedaan bermakna seiring berjalannya waktu.

c) Nilai massa otot lengan atas pada saat sebelum intervensi adalah $28,20 \mathrm{~cm}$, satu bulan intervensi $30,28 \mathrm{~cm}$ dan dua bulan intervensi 31,63 cm sehingga terdapat perbedaan bermakna seiring berjalannya waktu.

d) Nilai massa otot lengan bawah pada saat sebelum intervensi adalah $24,80 \mathrm{~cm}$, satu bulan intervensi
26,27 cm dan dua bulan intervensi 27,52 cm sehingga terdapat perbedaan bermakna seiring berjalannya waktu.

e) Nilai massa otot bahu pada saat sebelum intervensi adalah $101,20 \mathrm{~cm}$, satu bulan intervensi 104,95 cm dan dua bulan intervensi 106,68 cm sehingga terdapat perbedaan bermakna seiring berjalannya waktu.

Berdasarkan uji normalitas data peningkatan massa otot dalam melakukan kombinasi latihan beban dengan metode pyramid set dan konsumsi susu tinggi protein yang menggunakan Shapiro Wilk didapatkan data terdistribusi normal. Kemudian, dilakukan uji repeated anova didapatkan hasil bahwa paling tidak terdapat perbedaan yang bermakna nilai massa otot pada dua pengukuran $(\mathrm{p}=0,000)$. Untuk melihat perbedaan tersebut, dilakukan uji post-hoc paired wise comparison dengan hasil sebagai berikut: 
Tabel 3. Uji post-hoc paired wise comparison variabel massa otot sebelum, satu bulan intervensi dan di akhir bulan ke dua intervensi

\begin{tabular}{clll}
\hline Jenis Otot & $\begin{array}{c}\text { Kecepatan } \\
\text { peningkatan massa } \\
\text { otot }\end{array}$ & Perbedaan rerata (IK95\%) & P \\
& Awal vs bulan 1 & $-1,87(-3,103--(-, 630))$ & 0,003 \\
Otot perut & Awal vs bulan 2 & $-3,90(-5,462--(-2,338))$ & 0,000 \\
& Bulan 1 vs bulan 2 & $-2,03(-2,641-(-1,426))$ & 0,000 \\
& Awal vs bulan 1 & $-3,48(-5,085-(-2,219))$ & 0,000 \\
Otot dada & Awal vs bulan 2 & $-5,79(-7,288-(-4,279))$ & 0,000 \\
& Bulan 1 vs bulan 2 & $-2,30(-2,852-(-1,748))$ & 0,000 \\
& & & 0,000 \\
Otot lengan atas vs bulan 1 & $-2,08(-2,633-(-1,534))$ & 0,000 \\
& Awal vs bulan 2 & $-3,43(-4,064-(-2,803))$ & 0,000 \\
& Bulan 1 vs bulan 2 & $-1,35(-1,724-(-, 976))$ & 0,000 \\
& & & 0,000 \\
\hline \multirow{3}{*}{ Otot lengan } & Awal vs bulan 1 & $-1,47(-2,013-(-, 920))$ & 0,000 \\
& Awal vs bulan 2 & $-2,72(-3,625-(-1,808))$ & 0,000 \\
& Bulan 1 vs bulan 2 & $-1,25(-1,820-(-, 680))$ & 0,000 \\
& & & 0,000 \\
\hline \multirow{2}{*}{ Otot bahu } & Awal vs bulan 1 & $-3,75(-5,627-(-1,873))$ & \\
& Awal vs bulan 2 & $-5,48(-7,683-(-3,284))$ & \\
& Bulan 1 vs bulan 2 & $-1,73(-2,398-(-1,069))$ & \\
& & & \\
\hline
\end{tabular}

Berdasarkan uji post-hoc paired wise comparison pada tabel 3 di atas diketahui bahwa: (a) terdapat perbedaan yang bermakna pada nilai massa otot perut, otot dada, otot lengan atas, otot lengan bawah, dan otot bahu antara sebelum intervensi dan 1 bulan intervensi dengan nilai $p=0,003$ dan $\mathrm{p}=0,000$. (b) terdapat perbedaan yang bermakna nilai massa otot perut, otot dada, otot lengan atas, otot lengan bawah, dan otot bahu antara sebelum intervensi dan pada akhir bulan ke dua dengan nilai $\mathrm{p}=0,000$, (c) terdapat perbedaan yang bermakna nilai massa otot perut, otot dada, otot lengan atas, otot lengan bawah, dan otot bahu antara bulan pertama dan akhir bulan ke dua dengan nilai p $=0,000$. Berdasarkan hasil ini dapat disimpulkan bahwa intervensi kombinasi latihan beban dengan metode pyramid set dan konsumsi susu tinggi protein terbukti dapat meningkatkan massa otot pada responden seiring dengan lamanya waktu latihan.

Trend peningkatan massa otot pada responden dapat dilihat pada gambar 2 berikut ini:

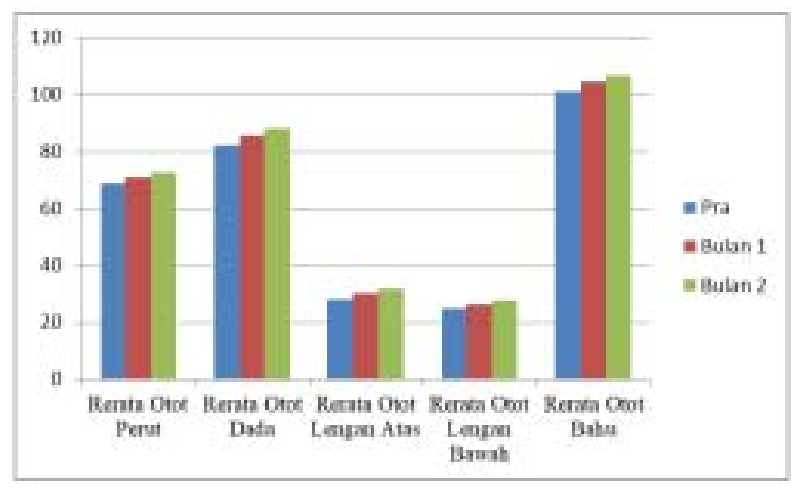

Gambar 2 Trend peningkatan massa otot responden

\section{PEMBAHASAN}

\section{Karakteristik responden berdasarkan umur dan indeks massa tubuh}

Berdasarkan hasil penelitian ini diketahui bahwa gambaran rerata umur responden adalah 19 tahun. Adapun umur terendah dan tertinggi responden adalah 15 tahun dan 26 tahun. Hal ini sejalan dengan teori bahwa latihan beban yang 
diberikan pada saat remaja dan dewasa akan memiliki kemampuan adaptasi fisiologi otot yang baik. ${ }^{8}$ Penelitian Bakhtiar (2010) tentang latihan kekuatan bagi atlet tenis menyatakan bahwa pada umur 15 tahun sampai 16 tahun laju pertumbuhan menurun, tulang dan ligamen menjadi lebih kuat. Pada rentang umur ini massa otot terus berkembang seiring dengan perkembangan kekuatannya. Pada umur 17 tahun sampai 19 tahun merupakan rentang umur untuk memulai upaya meningkatkan massa otot sekaligus kekuatan otot yang membutuhkan latihan beban. ${ }^{9}$ Sementara kekuatan otot maksimum umumnya dicapai pada umur 20 sampai dengan 30 tahun. Proses penuaan menyebabkan pengurangan kekuatan dan massa otot. ${ }^{10}$

Hasil penelitian ini menunjukkan bahwa terdapat peningkatan IMT responden setelah diberikan kombinasi latihan beban pyramid set dan konsumsi susu tinggi protein. Hal ini sejalan dengan teori bahwa konsumsi susu tinggi protein akan menyebabkan peningkatan berat badan dari penambahan massa otot dan IMT subjek. Peningkatan asupan energi akan menyebabkan pembentukan jaringan baru pada otot, sehingga apabila jaringan baru pada otot tersebut terbentuk akan menyebabkan peningkatan berat badan. Konsumsi proteinbermanfaat dalam penyediaan asam amino dalam jumlah yang diperlukan untuk pertumbuhan dan pemeliharaan jaringan tubuh. ${ }^{11}$

Hal ini sejalan dengan penelitian Harna (2017) tentang intervensi susu tinggi protein terhadap tingkat konsumsi zat gizi makro dan status gizi pada kelompok usia dewasa di kampus IPB yang menyatakan bahwa dengan mengonsumsi susu tinggi protein dapat meningkatkan berat badan secara signifikan. ${ }^{6}$ Hasil penelitian Zahtamal (2018) tentang pengaruh intervensi latihan beban pyramid set dan konsumsi makanan tinggi protein terhadap IMT dan massa otot remaja underweight mengemukakan bahwa terdapat perbedaan yang bermakna nilai IMT yakni peningkatan skor IMT selama melakukan intervensi kombinasi latihan beban pyramid set dan konsumsi makanan tinggi protein. ${ }^{12}$ Penelitian Yulni (2013) tentang hubungan asupan zat gizi makro dengan status gizi pada anak sekolah dasar di wilayah pesisir kota Makassar mengemukakan hasil yang sama bahwa terdapat hubungan antara asupan protein dengan status gizi. ${ }^{13}$
Susu protein yang diberikan kepada subjek pada penelitian ini merupakan pemberian suplemen protein selama 8 minggu. Suplemen protein yang digunakan merupakan susu whey protein produksi ultimate nutriton dalam 2 Scoop (70 gram) yang kandungannya adalah 280 kkal energi, 32 gram protein (64\%), 9 gram lemak (12\%) dan 20 gram karbohidrat (7\%). Rekomendasi dosis asupan protein yang optimal untuk meningkatkan massa otot adalah 20 sampai 40 gram. Mengkonsumsi asupan protein dapat memperbaiki kerusakan myofibril otot akibat melakukan latihan beban. ${ }^{14}$

\section{Pengaruh kombinasi latihan beban pyramid set dan konsumsi susu tinggi protein terhadap peningkatan massa otot}

Berdasarkan pengolahan data variabel massa otot, diketahui bahwa terjadi peningkatan rerata massa otot responden dari sebelum intervensi, satu bulan intervensi dan di akhir bulan ke dua intervensi. Hasil penelitian ini membuktikan bahwa intervensi kombinasi latihan beban pyramid set dan konsumsi susu tinggi protein berpengaruh terhadap peningkatan massa otot, yakni antara lain, otot perut, otot dada, otot lengan atas, otot lengan bawah, dan otot bahu. Responden melaksanakan program latihan beban yang berpegang pada prinsip beban berlebih (overload) untuk meningkatkan kemampuan otot seseorang secara periodik.

Hal ini sejalan dengan teori bahwa prinsip latihan beban berlebih (overload) pada dasarnya menekankan beban kerja yang dijalani harus melebihi kemampuan yang dimiliki oleh seseorang. Oleh karena itu, latihan harus mencapai ambang rangsang. Hal itu bertujuan agar sistem fisiologis dapat menyesuaikan dengan tuntutan fungsi yang dibutuhkan untuk meningkatkan kemampuan. ${ }^{15}$ Prinsip latihan beban berlebih (overload) yaitu bahwa pembebanan dalam latihan harus lebih berat dibandingkan aktivitas fisik sehari-hari. Pembebanan harus terus ditingkatkan secara bertahap sehingga mampu memberikan pembebanan pada fungsi tubuh. ${ }^{16}$ Latihan beban akan menyebabkan otot membesar. Pembesaran otot ini terjadi karena membesarnya serabut-serabut otot, bertambahnya jumlah kapiler di dalam otot, dan bertambahnya jumlah jaringan ikat di dalam otot. ${ }^{17}$ Ketika melakukan latihan beban, otot akan mengalami 
kerusakan. Untuk membantu proses perbaikan dan remodeling serat otot rangka yang rusak akibat latihan berat, diperlukan asupan protein untuk meningkatkan sintesis protein dengan mengonsumsi susu tinggi protein. ${ }^{11}$

Hasil ini sejalan dengan penelitian Zudanto (2016) tentang pengaruh metode pyramid set terhadap hipertrofi otot pada member fitness membuktikan bahwa adanya efek terhadap peningkatan massa otot setelah melakukan latihan beban pyramid set. Metode pyramid set membuat kinerja otot bertambah akibat dari beban yang meningkat sehingga volume otot pada tubuh menjadi meningkat. ${ }^{18}$ Penelitian Setiowati dan Hadi (2015) tentang pengaruh suplementasi protein terhadap konsumsi tubuh pada atlet membuktikan bahwa adanya efek asupan tinggi protein dengan massa otot yakni terdapat peningkatan massa tubuh tanpa lemak setelah diberi suplemen protein. Suplemen protein mempunyai kandungan protein yang cukup besar sehingga kebutuhan protein seseorang mengalami peningkatan. ${ }^{5}$ Penelitian Harna dkk (2017) tentang intervensi susu tinggi protein terhadap tingkat konsumsi zat gizi makro dan status gizi pada kelompok dewasa dan remaja di kampus IPB membuktikan bahwa peningkatan asupan protein akan membentuk jaringan baru, sehingga menyebabkan peningkatan berat badan. Konsumsi protein bermanfaat dalam penyediaan asam amino dalam jumlah yang diperlukan untuk pertumbuhan dan pemeliharaan jaringan tubuh. ${ }^{6}$ Hasil penelitian Zahtamal (2018) tentang pengaruh intervensi latihan beban pyramid set dan konsumsi makanan tinggi protein terhadap IMT dan massa otot remaja underweight mengemukakan bahwa terdapat perbedaan yang bermakna nilai massa otot yakni peningkatan skor massa otot selama melakukan intervensi kombinasi latihan beban pyramid set dan konsumsi makanan tinggi protein. ${ }^{12}$

\section{Otot perut}

Berdasarkan pengolahan data variabel massa otot perut, diketahui bahwa terjadi peningkatan rerata massa otot perut responden dari sebelum intervensi, satu bulan intervensi dan di akhir bulan ke dua intervensi. Perut merupakan area yang paling banyak lemak. Kurangnya aktivitas atau gerakan latihan dapat mengakibatkan menumpuknya lemak di perut. Untuk mencapai tubuh yang ideal dapat dilakukan olahraga atau latihan secara rutin agar lemak di tubuh terbakar. Latihan otot perut dapat mengurangi lemak tubuh dan meningkatkan massa otot tanpa lemak sehingga otot perut sedikit mengalami peningkatan. ${ }^{19}$

Hasil ini sejalan dengan penelitian Laksono (2016) tentang pengembangan model body weight training untuk latihan otot perut pada member fitness membuktikan bahwa latihan beban yang dilakukan dapat meningkatkan massa otot perut dan membentuk sixpack pada otot perut. Model body weight training untuk latihan otot perut dinilai sangat efektif dan memberikan respon positif terhadap member fitness. Otot yang ada di perut memiliki otot-otot yang kecil sehingga peningkatannya tidak terlalu besar. ${ }^{20}$

\section{Otot dada}

Berdasarkan pengolahan data variabel massa otot dada, diketahui bahwa terjadi peningkatan rerata massa otot dada responden dari sebelum intervensi, satu bulan intervensi dan di akhir bulan ke dua intervensi. Massa otot dada cenderung meningkat karena melibatkan hampir semua latihan yang tidak hanya untuk otot dada saja tetapi juga melainkan otot yang lain seperti otot bahu dan otot punggung. ${ }^{19}$

Hasil ini sejalan dengan penelitian Rabi dkk (2012) tentang pengaruh latihan beban terhadap peningkatan massa otot pectoralis mayor dan biceps pada remaja dan dewasa di Maha Gym Batubulan Gianyar membuktikan bahwa dengan pemberian latihan beban dapat menghasilkan peningkatan massa otot dada dan bisceps yang lebih besar pada kelompok usia dewasa dibandingkan dengan kelompok usia remaja. ${ }^{7}$ Pada penelitian Arhesa (2012) tentang efektifitas metode latihan pyramid dan pyramid terbalik terhadap peningkatan hipertrofi otot dada dan kekuatan otot dada pada atlet binaraga Jawa Barat juga membuktikan bahwa terdapat pengaruh yang signifikan metode latihan piramid terhadap peningkatan kekuatan otot dada. Hal ini dikarenakan otot dada memiliki penampang otot yang luas sehingga peningkatan massa ototnya cukup besar. ${ }^{21}$ 


\section{Otot lengan atas}

Berdasarkan pengolahan data variabel massa otot lengan atas, diketahui bahwa terjadi peningkatan rerata massa otot lengan atas responden dari sebelum intervensi, satu bulan intervensi dan di akhir bulan ke dua intervensi. Otot lengan atas termasuk otot kecil. Otot ini terbagi menjadi otot biceps dan triceps yang merupakan otot antagonis. Ketika otot bisceps berkontraksi saat melakukan latihan beban maka otot triceps berelaksasi dan sebaliknya. Latihan beban tersebut melibatkan dua otot yang saling berlawanan sehingga dapat meningkatkan massa otot. ${ }^{22}$ Pada saat melakukan latihan otot lengan atas, gerakan latihannya melibatkan dua macam otot atau lebih yang saling berhubungan. ${ }^{15}$

Hasil ini sejalan dengan penelitian Pambudi dan Hidayah (2014) tentang pengaruh latihan beban terhadap hipertrofi dan kekuatan otot bisceps pada member membuktikan bahwa rata-rata hasil post test lebih baik dibandingkan dengan rata-rata hasil pre test hipertrofi dan kekuatan pada otot bisceps. ${ }^{23}$ Hasil penelitian ini memiliki tujuan untuk menambah massa otot serta membangun kekuatan maksimal dan optimal. Perkembangan otot dapat diketahui dengan adanya penambahan beban setiap 10 sampai 20 hari.

\section{Otot lengan bawah}

Berdasarkan pengolahan data variabel massa otot lengan bawah, diketahui bahwa terjadi peningkatan rerata massa otot lengan bawah responden dari sebelum intervensi, satu bulan intervensi dan di akhir bulan ke dua intervensi. Otot lengan bawah termasuk otot kecil sehingga peningkatan massa ototnya tidak terlalu besar. ${ }^{22}$

Hasil ini sejalan dengan penelitian Putra (2014) tentang pengaruh latihan beban dengan metode pyramid set terhadap hipertrofi otot pada members fitness center gor UNY membuktikan bahwa terjadi peningkatan massa otot lengan bawah per 2 minggu selama 8 minggu. Metode latihan pyramid set memberikan pengaruh yang signifikan terhadap program hipertrofi otot, sehingga dapat diterapkan sebagai salah satu pilihan metode latihan yang efektif dan efisien untuk menaikkan massa otot sehingga terjadi hipertrofi. ${ }^{2}$

\section{Otot bahu}

Berdasarkan pengolahan data variabel massa otot bahu, diketahui bahwa terjadi peningkatan rerata massa otot bahu responden dari sebelum intervensi, satu bulan intervensi dan di akhir bulan ke dua intervensi. Otot bahu termasuk otot besar sehingga peningakatan massa ototnya cukup besar. Hal ini disebabkan karena pada saat latihan kemampuan bahu mengerahkan semua tenaga dari otot skelet yang didukung oleh otot-otot skelet punggung bagian atas, lengan atas dan lengan bawah bahkan didukung oleh semua otot skelet anggota gerak atas dalam satu kali kontraksi. ${ }^{22,24}$

Hasil ini sejalan dengan penelitian Putra (2014) tentang pengaruh latihan beban dengan metode pyramid set terhadap hipertrofi otot pada members fitness membuktikan bahwa terjadi peningkatan massa otot bahu. Peningkatan massa otot juga dipengaruhi pola makan yang disiplin, latihan yang rutin, istirahat yang cukup, dan suplemen yang tepat. ${ }^{2}$

Keterbatasan dalam penelitian ini adalah peneliti tidak mengontrol jumlah asupan kalori dan protein harian responden selama intervensi dan peneliti tidak melakukan kontrol terhadap faktor-faktor lain yang mungkin mempengaruhi hasil tes, seperti: waktu istirahat, kondisi tubuh, dan sebagainya. Faktor waktu istirahat berpengaruh terhadap massa otot selama melakukan latihan beban. Hal ini disebabkan karena tubuh membutuhkan istirahat agar otot-otot dapat pulih dan menyimpan energi. Waktu istirahat yang lama juga mempengaruhi potensi adaptasi otot. ${ }^{25}$

\section{SIMPULAN DAN SARAN}

Berdasarkan penelitian pada anggota fitness di salah satu Kota Pekanbaru yang mengikuti program latihan terdapat gambaran rerata umur responden adalah 19 tahun dengan umur terendah adalah 15 tahun dan umur tertinggi adalah 26 tahun serta gambaran IMT responden selama melakukan intervensi kombinasi latihan beban pyramid set dan konsumsi susu tinggi protein adalah meningkat serta ada pengaruh yang signifikan intervensi kombinasi intervensi latihan beban pyramid set dan konsumsi susu tinggi protein terhadap massa otot. Berdasarkan keterbatasan penelitian bahwa peneliti tidak mengontrol jumlah asupan kalori dan protein responden selama intervensi dan peneliti tidak 
mengontrol faktor-faktor lain yang mungkin mempengaruhi hasil tes, maka dapat disarankan kepada peneliti selanjutnya untuk dapat mengontrol jumlah kalori responden selama penelitian dengan food recall 24 jam dan dapat mengontrol faktorfaktor lain yang dapat mempengaruhi hasil tes.

\section{DAFTAR PUSTAKA}

1. Nasrulloh A. Progam Latihan Body Building dapat Meningkatkan Massa Otot Mahasiswa IKORA FIK UNY. J Media Ilmu Keolahragaan Indones. 2012;2:1-5.

2. Putra W. Pengaruh latihan beban dengan metode pyramid set terhadap hipertrofi otot pada members fitness center gor UNY [Skripsi]. Universitas Negeri Yogyakarta. 2015.

3. Guyton H. Kontraksi otot rangka. In: Buku ajar fisiologi kedokteran. 11th ed. Jakarta: Buku kedokteran EGC; 2008. p. 75-85.

4. Angleri V, Ugrinowitsch C, Augusto C. Crescent pyramid and drop-set systems do not promote greater strength gains, muscle hypertrophy, and changes on muscle architecture compared with traditional resistance training in well- trained men. Eur J Appl Physiol. 2017;0(0):0.

5. Setiowati A. Pengaruh Suplementasi Protein terhadap Komposisi Tubuh pada Atlet. Media Ilmu Keolahragaan Indones. 2015;3(2):3-7.

6. Harna H, Kusharto CM, Roosita K. Intervensi Susu Tinggi Protein Terhadap Tingkat Konsumsi Zat Gizi Makro Dan Status Gizi Pada Kelompok Usia Dewasa. Media Kesehat Masy Indones [Internet]. 2017;13(4):354-61. Available from: http://journal.unhas.ac.id/index.php/mkmi/article/ view/3157

7. Rabi G, Soethama R, Silakarma D, Ayu I, Wiryanthini D, Studi P, et al. Pengaruh latihan beban terhadap peningkatan massa otot pectorals mayor dan biceps pada remaja dan dewasa. Maj Ilm Fisioter Indones. 2012;2:52-7.

8. Myers AM, Beam NW, Fakhoury JD. Resistance training for children and adolescents. 2017;6(I):137-43.
9. Syahrial Bakhtiar. Latihan kekuatan bagi atlet tenis. J Ilmu Keolahragaan dan Pendidik Jasm. 2010;5(9):71-88.

10. Susilo S, Triyanti V. Prediksi Kekuatan Otot Pada Kegiatan Lifting. 2015;16:113-9.

11. Irianto DP. Panduan Gizi Lengkap Keluarga Olahragawan. II. Yogyakarta: CV. Andi Offset Yogyakarta; 2017.

12.Zahtamal, Restuastuti T, Restila R. Pengaruh intervensi latihan beban pyramid set dan konsumsi makanan tinggi protein terhadap IMT dan massa otot remaja underweight [Laporan Penelitian]. Pekanbaru. 2018.

13. Yulni. Hubungan asupan zat gizi makro dengan status gizi pada anak sekolah dasar di wilayah pesisir Kota Makassar. J Mkmi. 2013;Desember:205-11.

14.Jäger R, Kerksick C, Campbell B, Cribb P, Wells $\mathrm{S}$, Skwiat T, et al. International Society of Sports Nutrition Position Stand/ : protein and exercise. 2017;1-25.

15.Suharjana. Latihan Beban: Sebuah metode Latihan Kekuatan. J Ilm Kesehat Olahraga [Internet]. 2007;3(1):80-101. Available from: https://journal.uny.ac.id/index.php/medikora/ article/view/4719/4066

16.Irianto DP. Dasar-dasar Latihan Kebugaran. Yogyakarta: Lukman Offset; 2003.

17. Giriwijoyo S. Mulyana R. Fisiologi molekuler otot. In: Ilmu faal olahraga (fisiologi olahraga). Bandung: PT Remaja Rosdakarya Offset; 2012. p. 192-212.

18.Zudanto H. Pengaruh metode latihan pyramid set terhadap hipertrofi otot pada memeber fitness ros-in hotel yogyakarta [Skripsi]. 2016.

19. Makara RB. Perbandingan efektivitas latihan situp dan latihan plank terhadap kekuatan daya tahan otot perut dan penurunan lingkar perut [Skripsi]. Universitas Negeri Yogyakarta; 2018.

20.Laksono BA. Pengembangan model body weight training untuk latihan otot perut. Universitas Negeri Yogyakarta; 2016.

21. Arhesa S. Perbandingan metode latihan piramid normal dan piramid terbalik terhadap peningkatan hipertrofi otot. 2012;45-51. 
22. Snell RS. Pendahuluan. In: Anatomi kliinis berdasarkan regio. 9th ed. Jakarta: EGC; 2013. p. 7-12.

23.Pambudi N, Taufik Hidayah. Pengaruh latihan pola straight-set dan drop set terhadap hipertrofi dan kekuatan otot bisep pada member Fik Fitness Center Unnes Semarang. J Sport Sci Fit. 2014;3(2):6-10.
24. Olber M, Heatham S, Alamh P, Anney W. Characteristics of shoulder impingement in the recreational weight training-population. J Strength Cond Res. 2014;28(4):1081-9.

25.Holmes CJ. The effect of rest period lengths on muscle hypertrophy and intraexercise performance. University of Central Missoury; 2016. 